\title{
Religious cultural Arts in mentality system of Javanese society: A critical analysis to the dynamics of 'Keris' development as a religious archaelogy
}

\author{
${ }^{1}$ Mpu Tabah Chalifatah Aji* \\ 1Nunuk Suryani \\ 1Akhmad Arif Musadad \\ ${ }^{1}$ Master oof History Education, Sebelas Maret University, Indonesia \\ *Corresponding Author \\ Email: mputabahca@gmail.com
}

\begin{abstract}
Religion in a contextual meaning as a social practice contributes to the formation of religious cultural arts as well as religious archaeology. This research context discusses about 'Keris' as a form of religious cultural ideas and a full comprehension of the supernatural power outside the human himself (religiousness value). This research becomes significant to do since in the middle of global extremism lifting up again 'Keris' as a part of networking collective as a Javanese wisdom of life. Moreover the implication is that the religious philosophical value which is applied universally and symbolized in 'Keris' archaeology is able to lead to the realization of cultural identity which tightens nationalism in heterogeneity not homogeneity, creates awareness of the preservation of the religious archaeology as a form of religious cultural ideas. This research uses an ethnography qualitative research supported by interviews along with Talcon Parson's the theory of Societies. It located in Solo, Jawa Tengah. The result of the study also shows that the dynamics of 'Keris' development genealogically is not only as a part of self-identity of Javanese society (invulnerability symbol). Kris in this case is also related to the society's mentality system which is close to the philosophical value of religiousness which is fully comprehended as ethics and wisdom of life.
\end{abstract}

Keyword: religious culture; mentality system; 'Keris'; archaeology; Java

Received:

25 June 2019
Revised:

30 August 2019
Accepted:

Published:

31 August $2019 \quad 31$ August 2019

\section{INTRODUCTION}

The dynamics of cultural development shows how the process of a society transforms, develops, preserves, and revives aspects of social life including material culture. According to Koentjaraningrat $(1987: 15)$ the form of culture that develops in the social structure determines the style of thought, action, and ultimately the cultural outcome of the material. The results of physical culture indicate that the value has been accepted as a collective agreement 
Aji, Suryani, Masadad, EduLite: Journal of English Education, Literature, and Culture Vol.4, No.2, August 2019, 247-260 DOI: http://dx.doi.org/10.30659/e.4.2.247-260

and becomes part of the supporting identity. The analysis of material objects is an attempt to voice the symbolic value contained in the object both in the process of its creation, as well as the culture that creates it, as well as how the material objects (artifacts) are created.

The study was then developed by reconstructing how material objects operate in cultural systems, so that they are able to become part of cultural identity. Archeology rests on material objects, this is where archeology becomes a part that reveals core values (core value) cultures that are now developing in the archipelago, including Java. The concept of core values was first introduced by Francis Hsu to refer to values that are specifically embraced and favored by a culture, resulting from mutual agreement, and made into a cultural identity of a society (Nurhadai, 1987:15). Cultural identity becomes a sign of the civilization's journey, which is accompanied by practice, and filled with symbols as a sign of existence, and differentiates it from other communal entities.

One cultural identity that would be discussed as corpus this research, namely 'Keris'. The termination of 'Keris" meaning in this study is aimed at an object that has two main parts, the part of the 'Keris' blade (including pesi*), and the part of ganja. Parts of the blade and pesi symbolize the form phallus, while ganja symbolizes the yoni (Arifin, 2006:15). In Javanese philosophy, the unity between phallus and yoni symbolizes hope for fertility, eternity (preservation), and strength. An object can be said to be a 'Keris' if it meets the following criteria; the 'Keris' blade must form a certain angle towards ganja, not perpendicular. The position of the 'Keris' blade which is tilted or inclined philosophically is a symbol of the Javanese character, the awareness of the position of the individual with any rank, position and position, must always submit to the creator, and respect others.

'Keris' that developed in the Javanese mentality system were initially directed as material objects that have magic and magical value, as well as part of a symbol of prestige, empowerment, and objects with high aesthetic value. As a symbol, the 'Keris' in the dynamics of its development cannot be separated from the various discourses that are formed as an effort to produce and reproduce it. The dynamics of the development of the 'Keris' in the context of the social transformation of religiosity is one example of a material object that continues to develop in a form, discourse, meaning, and appreciation.

'Keris' in Warto's perspective developed in Java and were used between the 9th and 14th centuries. This weapon is divided into three main parts: the eye, upstream, and the holster. While appreciation, meaning is often associated with mysticism by the Malays in ancient times, namely, surrounded by the belief that the 'Keris' has its own spirit. (Warto, 2008: 114).

Reality shows that the dynamics of 'Keris' development in production and reproduction are not only accompanied by the creativity of master as a 'Keris' maker, but it is colored by various discourses and discourses on symbolic meaning. The symbolism of the 'Keris' continues to be interpreted as a form of efforts to reproduce preservation, and not infrequently for various purposes. The value of the kris also undergoes transformation from sacred to profane in the Javanese community mentality system.

'Keris' creation is a combination of desires, hopes, goals, and desired benefits from the buyer of the 'Keris' with the taste, intention, and creativity of 
the master who is manifested in the symbols in luk, dhapur, and pamor of the 'Keris'. In the process, the master is included in the dimensions of general symbols that apply in Javanese society. If the Javanese 'Keris' is analyzed from the perspective of symbolic metaphysics, then the meaning of the symbolization of the 'Keris' in the lay group (the general public) is more vertical-transdental. Meanwhile, in special group (intellect) symbolization of Javanese kris with double dimensions, namely vertical-transdental, as well as horizontal-immanent. Then in the new group (who consider the 'Keris' as an art object) the symbol of the Javanese 'Keris' is more horizontally-immanent (Siswanto, 2012:70).

The social structure of the "Keris" position in Javanese society social system is not only in the level of cultural objects, but across the system of community mentality which is manifested by social, economic, cultural, and religious influences. The meaning of the 'Keris' is not only based on its usefulness, but is related to the beliefs that are lived out, even in its time associated with religious elements. Religion contributes to the meaning of the 'Keris' as a spiritual work. This is easy to understand considering that religion in everyday life is part of social practice. Religion is a guideline, providing an overview, ethics, rules and guidelines for behavior patterns in social life. So that as a social practice religion provides a contribution to the formation of religious cultural arts to religious archeology.

'Keris' in the dynamics of religious development in the archipelago, especially Java shows its flexibility as a form of religious archeology that continues to be developed. 'Keris' is never extinct as a result of the creation of religious culture, but continues to transform in renewal following its era. The proof is that the 'Keris' in the reproductive process is no longer a symbol of nobility, heritage and fortune, but as a cultural object that is preserved.

The shift in the current context is confronted with the culture of mass as an alternative preservation. There must be a fundamental value that is never lost from the appeal of the 'Keris', namely the value of humanism, religion, and philosophy. For example lajer 'Keris' (straight) shows that humans must live straight. 'Keris' luk, symbolizing the effort to achieve human life goals must have flexibility.

'Keris' is positioned as part of traditional weapons. The 'Keris' in this study is associated as a symbol of authority, wisdom, and life (Endrawati, $2015: 137)$. This context is in line with Cassirer's statement which states that humans are animal symbolicum, and Javanese people are communal with various symbols. So it can be concluded that the 'Keris' does not only have a pile of facts, but has a psychological meaning from the Javanese community (Cassirer, 1994:64).

Based on this explanation the researchers were interested in reconstructing the dynamics of the development of the 'Keris' as a religious archeology of the Javanese people. Genealogically looking at the process of its creation, the element of culture that creates and supports its development in social transformation, and how it operates in the structure of Javanese society. The operation of the 'Keris' in the social structure will be seen in relation to the appreciation of religious culture in the system of the mentality of the Javanese community. In the perspective of the researcher, the study of 'Keris' symbolism in relation to religious archeology and the community 
Aji, Suryani, Masadad, EduLite: Journal of English Education, Literature, and Culture Vol.4, No.2, August 2019, 247-260 DOI: http://dx.doi.org/10.30659/e.4.2.247-260

mentality system will contribute to the reinterpretation of a 'Keris' (indigenous psychology), inheritance of religious philosophical values, and humanism in the rules of living practice as cultural identities.

This research is important to do considering that in the midst of global extremism, re-raising the 'Keris' as part of its networking collective memories will build an awareness of the importance of maintaining the noble philosophical values contained in it as a wisdom of life. Moreover, each region has a variety of characteristics of 'Keris' which in its historical journey are part of a unifying communal bond and spread in various countries, such as: Malaysia, Thailand, Philippines, and Vietnam.

The early development of the 'Keris' was closely related to migration, cultural results, and humans in the Southeast Asia region. Archeologically it is interpreted that between the 5th century BC and the 2nd century AD there were forms of culture based on the intelligence of bronze castings, the dynamics of Dongson's culture. The proficiency of bronze castings and the addition of the ornamental forms were then transmitted to all contemporary artists in the Southeast Asian region, therefore Dong-son bronze artefacts were considered as one of the binding civilizations of the Southeast Asian nations (Poesponegoro and Notosusanto, 2008:27-31).

Restatement and relentless narratives related to 'Keris' symbolism will help contribute to strengthening the dignity of the nation with noble philosophical values that are relevant to the present context. The implication of religious philosophical values that are universally applicable and symbolized in 'Keris' archeology is able to encourage the realization of cultural identity that strengthens nationalism in diversity rather than uniformity, creating awareness of the preservation of religious archeology as a form of religious cultural copyright.

\section{METHOD}

This research is under ethnography qualitative research. The location of the research was carried out at the Surakarta 'Keris' Museum, located at J1.Bhayangkara No.2, Sriwedari, Laweyan, Surakarta City. The object of research is Javanese people who have knowledge of 'Keris'. The research was conducted with literature studies, interviews, and direct observation. Analysis of the symbolic values in the 'Keris' is associated with the process of creation (value symbolic religious which surrounds), the culture that creates (the dynamics of the development of religiosity) and supports the dynamics of its development (the mentality system that reproduces it), as well as how the material objects (artifacts) are created and manifest (the culture of the material). The study was then developed by reconstructing how these objects operate in cultural systems.

This research refers to Cassier's perspective which states that humans are animal symbolicum, then the 'Keris' does not only have a pile of facts, but has a psychological meaning. In line with the opinion of Talcot Parson inside Theories of Society, which includes that cultural system, controls social norms, personality motives, and self-concept of acting. So that the 'Keris' in this case is not just a cultural object without symbolic meaning, nor merely has functional value, but rather touches the sides of appreciation (religiousness) its supporting community as religious archeology. Critical study is carried out on 
the meaning given, explained, the discourse that is delivered and discourse that continues to be rolled out in the Javanese mentality system. As the core of this research in the perspective of the researcher will be able to show the mindset, style of action, the level of religious acceptance that is lived out as the ideal life ethic of Javanese society symbolized in the form of 'Keris' from sacred to profane.

\section{RESULTS AND DISCUSSION}

\section{Art of Religious Culture in Javanese Society}

The Javanese people in the perspective of this study refer to individuals who are still preserving Javanese cultural values as part of their cultural identity. Javanese individuals can be born of Javanese descent, have an identity of Javanese and most importantly in a personal and social manner cognitive, affective, and psychomotor awareness to carry out the values of Javanese culture. Geographically and historically more specific and factual, Javanese people in this study are regions that consciously preserve Javanese culture based on the culture of the Yogyakarta Palace, and Surakarta.

The Javanese community in the perspective of cultural values has a belief in existence universe (big universe) macrocosm, and little universe (small universe) microcosm. Macrocosm pointing to the universe, whereas microcosm relating to the conscience stored in human beings. According to Niels Mulder (1973) this view gave birth to a Javanese (Kejawen) perspective that was syncretic and tolerant, so it became the basis for receiving input from new religions. The arrival of the new religion was not hostile, but became part of the inspiration of the Javanese (Kejawen) as Javanese religion, or in Koentjaraningrat's perspective it was known as the Jawi religion.

The teachings of the followers of the Jawi religion according to Parsudi Suparlan's research are related to the concept of "sangkan paraning dumadi", namely towards the origin and purpose of the event. This teaching becomes part of a mental attitude, mental attitude towards others with nature, and maintaining the balance and harmonization of Javanese society (Susetya, 2007:38).

The mysticism of Javanese society views human life as a very small part of the universe. The realm of the human mind which consists of the macrocosm and the microcosm becomes a view of life as well as the abstraction of life experiences.

The basis of Javanese beliefs or Javanism is the belief that basically the nature of everything in the world is one and is a unity of life. Javanism views human life as closely related to the cosmos of the universe, so that human life is a journey full of religious experiences. The emergence of religious consciousness shapes culture (Wisnu, 2012:18-20). So that basically attitudes, lifestyles and activities must be the basis for the growth of harmony, balance and harmonization of the Javanese community. In social practice as a system of mentality, and the basis of the beliefs that underlie action, religion as a Javanese view of life gave birth to the art of religious culture, as a form of civilization development, manifestation of existence, and internalization of ideas in the social structure of Javanese society. In line with Talcot Parson's statement in Theories of society, which makes the cultural system as a 
Aji, Suryani, Masadad, EduLite: Journal of English Education, Literature, and Culture Vol.4, No.2, August 2019, 247-260 DOI: http://dx.doi.org/10.30659/e.4.2.247-260

controller of the personality system so that balance in social transformation is always maintained.

The art of religious culture is proof that in social life and the structure of religious society it becomes a form of social practice. As Franz Magnis Suseno (2001) argues that the struggle of Javanese people with nature can help Javanese individuals to lay their social and cultural foundations communally (Endraswara, 2013:38). Javanese religious cultural arts are also based on noble philosophy, which underlies the behavior of "memayu hayunung bawana". This nobility is related to the concept of behavior to maintain world peace, as a deposit of the noble values of the product (creativity, taste, and intention). Therefore, in its development 'Keris' became a part that was closely related as one of the material of Javanese culture both philosophically as a symbol of fertility, sustainability (lingga yoni), as well as functionally as a weapon to maintain peace.

Historically genealogy of the 'Keris' in the system of mentality and structure of Javanese society can be understood from the philosophical conception of agrarian that is understood by Javanese society. This agrarian philosopher has given birth to a 'Keris' material as a real manifestation of the intermediary means between supernatural and human forces in the form of religious cultural arts. The main purpose is not just syncretism, but rather with the level of trust and acceptance of the perpetrators of the formation of artistic, magical, religious culture, before discovering its functional aspects (Sumarjo, 2002:152). Javanese society in animistic culture and dynamism uses many rituals slametan, alms earth as a belief in maintaining fertility, food abundance, and keeping away all distress. The position of the kris as a copyright of religious culture is related to one ritual ritual, namely part of ubo rampe (equipment) in the ceremony.

Cultural art is inherent in religious values because the entity is one of the instruments of internalizing religious values. Jajachim Wach (1998) states that religion has an effect on immaterial human culture that the mythological collective relationship depends on thinking of God, namely the relation to, how individuals think, appreciate, and imagine (Wach, 1984:187). Reinforced by Geertz (1992) 's initial statement that revelation forms a psychological structure in the minds of humans that forms logical consistency as a way of life to direct behavior, and not only produce culture immaterial but also in the form of art, carvings and buildings, including the 'Keris' (Geertz, 1992: 13).

The culture of religion in Javanese society continues to grow and develop in line with the development of history in the objective conditions and lives of its followers (Tule, 1994: 159). Culture of religion can be said to never die, but transformed into renewal following its era. This fact is shown historically. Historically the religious culture that developed within the scope of Javanese society showed the influence of religious renewal which came as a form of communication network. The belief about the existence of magical objects, spirits in animist beliefs and dynamism gave birth to renewal of cultural renewal when faced with communication networks in the trade routes in the archipelago. The results of the religious culture that embodied animist beliefs and dynamism, merged with various new beliefs both Hindu-Buddhism, Islam, and Christianity with their respective archeological features. 
Even in the formation of the early culture it was known that the migration carried out by the ancestors of the ancestors, gave birth to various results of religious culture in the form of objects and rituals. This is reinforced by his archeological heritage, and corroborated by the statement of Robert Von Heine Geldern, an archaeologist who stated that large migrations to the Southeast Asian region were accompanied by cultural dispositions (Munandar, 2010). Geldern in this case based his theory and showed evidence of the cultural inheritance of migrants based on Megalithic culture which was accompanied by the belief in developing ritual ceremonies which spread almost throughout the archipelago. For Geldern this context shows that religious culture is a form of communal binding when Maden culture and cultivation are starting to grow in the archipelago.

The development of religious culture was also demonstrated by the arrival of the Dongson nation in the 5th century $B C$ to the 2 nd century AD which brought the intelligence of bronze castings (Pusponegoro and Notosusanto, 2008:27-31). At this time various artifacts were developed (candrasa, short swords, cutting knives, axes with various ornaments). Shows that the people supporting Dongson's culture have high aesthetic values, and their use is also related to ritual ceremonies, as offerings, ubo rampe (equipment), and offerings. The proficiency of bronze castings and ornaments was then transmitted to contemporary artists in the Southeast Asian region. The implication was born in the syncretic religious culture between animist beliefs of dynamism by using various material objects, the forerunner of the 'Keris' in the worship of ancestral spirits (ancestor worship).

The entry of Buddhist Hinduism into the social structure of society helped shape the dynamics of the development of the Javanese religious culture. Religious archeology in the physical form of metal can be traced to influences from India, especially Shivaism. As written in the inscription of Dakuwu (6th century) shows Indian iconography that displays "Wesi aji", as; trident, kudhi, sickle, and aromatic 'Keris' (Budisutrisna, 2009: 23). This reality identifies that religious archeology in its development is able to adapt to conceptions, ideas, teachings, ideas that are internalized by religious adherents as a belief, recreated for the sake of worship by adjusting teaching values, and functionally helping human production activities.

The order of religious culture strengthened in Java especially with the development of kingdoms with Hindhu-Buddhist styles, and Islam in the archipelago, especially Java. The division of the royal era which helped make the 'Keris' as part of religious archeology, namely: first, ancient times. These days range from $125 \mathrm{AD}-1125 \mathrm{AD}$ which included the kingdoms of Purwacarita, Medang Kamulan, Kahuripan, and Kediri. Second, Madya Kuno, in $1126 \mathrm{AD}-1250 \mathrm{AD}$, covering the kingdoms of Jenggala, Kediri, Pajajaran, and Cirebon. Third, Sepuh Tengah in 1251 AD 1459AD, included the Kingdom of Jenggala, Kediri, Majapahit, Blambangan. Fourth, mid, from 1460 to 1631 $\mathrm{AD}$, covering the kingdoms of Demak, Pajang, Madiun, and Mataram. Fifth Nom (Young), in 1614 until now covering kingdoms, Kartasura, and Surakarta (Warto, 2015:114). It was at this time that the laying occupied a special place as a sign of greatness, ajisaka, tatabusana jangkep raja.

The conclusion that deserves to be drawn as a common thread, namely the history of the formation of religious culture in communal Javanese society 
Aji, Suryani, Masadad, EduLite: Journal of English Education, Literature, and Culture Vol.4, No.2, August 2019, 247-260 DOI: http://dx.doi.org/10.30659/e.4.2.247-260

shows that religion becomes a system of mentality forming habitus, giving birth to material objects, and giving birth to mutual recognition as identity. The art of religious culture is philosophically rooted, literally preserved and disseminated its meaning to all future generations, acknowledged, accepted, transformed with the spirit of the times so as not to fade. Symbolically the religious culture in Javanese society is not merely a product of cultural creativity, but also touches other sides, other meanings, the manifestation of essential values of the ethics of life, and provides a description of rationality, beliefs, and beliefs surrounding the results of religious culture and its material.

\section{'Keris' in the Javanese Community Mentality System.}

A cultural object is related to the ideas, ideas, and mindset, and the supporting culture adopted by the entity that creates it. 'Keris' is a form of thought that is adapted to the supporting culture and manifests in physical form. The meaning of the 'Keris' is not only done by looking at the functional, but also rebuilding the root of thought agency who produce and reproduce it in social structures. Consequently, viewing 'Keris' is not merely a weapon, nor as an aesthetic product of Javanese ideal clothing. 'Keris' is still able to survive in society instead it lies in its function as a sharp object, but related to its symbolic functions and family heritage. Belief in mystical 'Keris' that is auspicious, antique things, as well as other symbols as part of a Javanese fashion age man (kejawen Jangkep) in wedding ceremonies (Endrawati, 2015: 137). 'Keris' is also a product of religious culture that has value honorable and symbolic meaning. 'Keris' as a symbolic object in the Javanese mentality system contains deep meaning about certain moral and ethical messages, which describe the conception of the natural world of the psyche. As a society that has a belief in the 'Keris' in the mentality system of the Javanese society it contains meaning with pedagogical values as a mindset of its cultural identity of Javanese (Darmojo, 2016:67).

For the Javanese people, the 'Keris' is a creation of a community that has high philosophical values. Kris is the philosophy of the union of servants and their Lord, this can be captured from the phrase "curiga manjing jumbuhing warongko lusti gusti", which means; the union of the 'Keris' and the warangkanya is a symbol of the union of humans / servants and their God " (Wijayanto and Sudrajat, 2011: 151). The view that he is a servant with his creator God tries to unite, merge, without distance. 'Keris' with its completeness (blades, warangka, hulu, etc.) is a language expressing the desires, hopes, ideals, goals, identity of its owner (human) which is realized as an embodiment of understanding the value of fusion with gusti in the form of Manunggaling Kawula Gusti 'Keris' also hints at marriage and fertility between Shiva and Brahma, so that in the system of Javanese mentality the term is also known "Kridaning manungsa katon saka curigo" , meaning that what a person does (the behavior of one's life) will appear from his kris.

'Keris' literally in Javanese comes from "Kekeran aris". Kekeran has the meaning of fence, barrier, warning, and controller. Aris, in this case it has a calm, cautious, and subtle meaning (Wijayanto and Sudrajat, 2011: 151). So in reality the kris means harmony and harmony, steadfastness and patience, and honesty. Kris in Javanese social practices is associated with human 
relations, which requires that one must be mutually compatible ngeker, fence, warn, and control wisely. In the context of his seminars, it must also be associated as a symbol of greatness (social status), in fact in a more populist life, outside the life of the 'Keris' palace is a part of daily life that is more functionally interpreted.

The history of 'Keris' travel in Javanese society is not only literally disseminated linguistically. The dynamics of the emergence and development related to Dongson culture, then shifted along with the entry of Buddhist Hinduism, and Islam, thus giving birth to religious magical meaning, and having different articulations from the functional. So that in its development, the 'Keris' is not only an offering tool, but also media that facilitates the food production process. Kris has transformed with the meaning of denotation and connotation. Moreover, the Javanese people are all places pasemon (symbolism / symbol) (Herusatoto, 2008: 154). As a gesture that manifests the mind, will, and delicate Javanese taste. Therefore the meaning stored in the 'Keris' is not only the meaning of denotation, but also the connotation for the meditation to convey the message, compile the epistemological system and beliefs held, and a sign that must be articulated according to the context, interests and situation.

The term 'Keris' mixed with animist beliefs of dynamism, then Hinduism gave birth to the meaning of the kris in the structure of Javanese society as a mystical object. Some 'Keris' are considered to have luck and beautiful. Kris also mixes with appreciation related to the world of macrocosm and microcosm. Philosophically agrarian as a symbol of sustainability. Being in a certain moment in a magical atmosphere mixed with beliefs about pulung, and understanding safety, and the power of those who have to achieve their goals. This reality has been known in several ancient inscriptions, namely in the form of a legacy bronze plate found in the Central Coral in 748 Saka, or 842 AD which mentions several types of offerings to set Poh as a tax-free area. The offerings include Kres (Kris), Wangkul (spear), tewek punujan (double-edged weapon), and dwisula (Harsinuksmo, 2004: 24).

The spread of the 'Keris' in the mindset of the community can also be proven by the proverbial expression "Ba'bujang jolong ber'Keris", that means the 'Keris' can replace the presence of a man in a marriage ceremony when he is unable to attend because of war. This position places the 'Keris' in a high position. The clearer in the system the mentality of the Javanese 'Keris' has "Order, demand, and spectacle". Kris is made with a touch of taste and expression to meet the rules of visual beauty (spectacle). 'Keris' is also made with the demands of the standard (rule) complicated in the depths of religious, magical and mystical meaning (order). The 'Keris' is practically as in the phrase "babujang jolong ber'Keris" with all its forms and completeness, there are demands and meanings of life.This will be more easily understood considering that in the Javanese mentality system the symbolism of the kris can be viewed from a number of things, including; material aspects, aspects of form (kitchen), aspects of prestige, from aspects of warangka materials used.

'Keris' symbolizes concrete ideas, manifested through the overthrow of ideas (abstract) that regulate human activities in the social system, so that these activities give birth to their material culture (artifacts) as a hereditary cultural heritage. This process of embodiment of the 'Keris' gave birth to the 
Aji, Suryani, Masadad, EduLite: Journal of English Education, Literature, and Culture Vol.4, No.2, August 2019, 247-260 DOI: http://dx.doi.org/10.30659/e.4.2.247-260

religious social functions of the 'Keris'. 'Keris' in the viewpoint of Javanese people's mentality is interpreted in depth as a symbol, this symbolism continues to develop along with the level of acceptance of society, thus coloring the pattern of the dynamics of development of the 'Keris' itself. Specifically this symbolism gave birth to the polarization of the meaning of the 'Keris'. The symbolization of the 'Keris' in the lay group (the general public) is more of a nature vertical-transdental.

Transdental life emphasizes spiritual, elusive, occult and abstract things. Vertical transcendence means the relationship between the person and what is believed to be a force outside of him, so this religious magical nature is carried out with respect. This context also caused fear in Javanese society, which appeared in pamali, ora ilok, etc. The transcendence of the Javanese 'Keris' also seems very clear from the symbol of money developed by the Javanese people regarding the unity of human desires and hopes with God (manunnggaling kawula gusti) (Siswanto, 2012).

Whereas in the special group (intellect) the symbol of the Javanese 'Keris' has a double dimension, that is vertical-transdental, all at once horizontalimmanent. 'Keris' with immanent horizontal dimensions based on the understanding of the kris as a human creativity that is filled with symbols that are also for humans, this can be seen from the form, warangka, hulu, bilah (Luk, dhapur, pamor). Then in the new group (which considers the 'Keris' as an art object) the symbol of the Javanese kris is more dimensionless horizontal-immanent (Siswanto, 2012).

The meaning of the 'Keris' in the lay system of Javanese mentality, hear from generation to generation the existence and existence of the 'Keris', attempts to reproduce the 'Keris' in the dynamics of the existence of the 'Keris' itself, not based on the parts of the 'Keris'. 'Keris' in this order is still sacred, only possessed by individuals with pulung, supernatural powers, and has a magical attraction that is able to move, help human life. 'Keris' has a magical element that is articulated as a 'Keris' with auspicious purposes, and sacred mystical interests.

In contrast to the first point of view, the dynamics of genealogical development of the 'Keris' also shows that the production and reproduction process of the 'Keris' in the system of mentality of the kejawen community gave birth to the meaning of the 'Keris' as a heritage object. His interpretation continues to develop in mystical, historical, ethical, philosophical and religious social meanings. This group generally believes in various forms in the 'Keris' accompanied by rational symbols and meanings. The agency this has become cleverly clever who continues to disseminate the philosophical meaning of the 'Keris' as a wisdom of Javanese life in living life to the wider community.

'Keris' mystical religion, and philosophical has a double dimension, both horizontally and vertically, as well as immanent and transcendent. Transcendental religion can be seen from the expectations of the Javanese people that the 'Keris' they created, are preserved, are maintained to produce objects that also have a transcendent dimension (to have tuah) to maintain safety. In conclusion the symbols on the warangka, hulu, luk, dhapur, and pamor 'Keris' are a union of physical existence and doctrinal symbols of life and the hope of the existence of tuah with magical powers that can be utilized by humans. 


\section{Dynamics of 'Keris' Development as Religious Archeology}

'Keris' as a religious archeology of Javanese society is not seen as sensually accepted by the five senses, but rather in an inner experience or in Zoetmulder's perspective it is mentioned as an aesthetic experience (a summary of aesthetic and mystical or religious experience) (Zoetmulder, 1965:327). This reality causes the production process of the emperor's 'Keris' to be required not to sink into sensual and phenomenal natural beauty, but to reach the process dhya'na (concentration) and darana (the image of the god arises while the other images disappear) and he arrives in Samadhi, the loss of self-awareness because he has been absorbed by the Gods. This conception supports the statement that in the process of development of individual civilization, it will always be associated with a factor of trust.

'Keris' production is carried out by a master. In the social status of the Javanese people during the kingdom, Empu was a person of high degree, for several reasons; first, masters are individuals who understand the concepts of life and divinity. Second, the master is also a psychological expert, understanding of the character and nature of this makes the master able to make 'Keris' according to his ordering. Third, it is usually a kanuragan expert, so the 'Keris' can be used properly. Fourth, as an artist with a high aesthetic spirit. Fifth, the master is also a political expert, because the production of the 'Keris' is closely related to the political conditions of the kingdom during his time. Sixth, the master also understands anatomy so that it will support the mobility of the buyer. Finally, a master is a literary expert who fully understands his philosophical social values.

Looking at the context of 'Keris' production carried out by people who have special abilities, it shows that the 'Keris' occupies a special position in the structure of society. This structure will be closely related to Javanese philosophy as a concept of life. So, discussing the dynamics of the development of the 'Keris' as religious archeology cannot be separated from its philosophy. The philosophy of Javanese society with knowledge of God (religion) is always in harmony, so that in the realization of all the products of Javanese culture it is very close to the knowledge of Godhead. Thomas Munro in the naturalistic sense, about spirit and spirituality can be said that all art is spiritual. All art involves some perceptual and imaginative reorganization in the sense of a sensory medium of form and expression (Munro, 2007).

'Keris' in the dynamics of its development as religious archeology can be interpreted in several ways, first symbolically can be viewed from the aspect of material. The iron-based 'Keris' Karang Kijang has a cold, patient meaning, pulosani iron for the symbol of authority, career, and wealth. Mangangkang iron has a meaning when going to get sustenance, walulin iron which is beneficial for fertility in agriculture, facilitating matters of a matter, and being respected. Finally, which comes from winduaji iron, this 'Keris' has magical benefits for safety (Prasena, 2009).

Second, it can be seen from its parts. For example, based on research and review of the Warto "dapur "Keris" also has religious meaning that functions as a life guide, among others, as follows; Dapur Bruncak, meaning that humans can be born spiritually back, return fitrah, show fortitude to live. The gathering to show the family's comfort, the Sabuk Inten symbolizes prosperity and luxury, Sengkelat symbolizes the stability of the bearer in 
Aji, Suryani, Masadad, EduLite: Journal of English Education, Literature, and Culture Vol.4, No.2, August 2019, 247-260 DOI: http://dx.doi.org/10.30659/e.4.2.247-260

various fields. Nagasara, symbolizes the highest authority. Such mindset and understanding encourage the dynamics of the development of 'Keris', often associated with ritual ceremonies, both during the cultivation of Javanese people. (wiwitan), or in marriage (mantenan), and not infrequently used by prewangan shaman which is recognized by some Javanese people. Prewangan shaman is a community of leaders who usually help Javanese calculations in making important days for marriage, farming, building houses, and healing or medical aids. Prewangan shamans are closely related to 'Keris', because in practice the 'Keris' is part of the ritual equipment.

Apart from the parts of the 'Keris' and its symbolic meanings, this research will again direct the dynamics of the development of the 'Keris' as religious archeology from the point of view and its relation to the results of religious culture. Again, it is important to remember that based on archaeological and sociological data (community behavior), it can be seen that most of the fact that the 'Keris' is often involved in religious activities, even from the beginning of its production one of the 'Keris' functions was made to meet spiritual and religious needs. 'Keris' in spiritual and religious religion are found in the concept of "the Five Substances", namely; Dewa Zadnya, Manusia Zadnya, Pitra Zadnya, and Resi Zadnya. This concept is even found in Hinduism in Bali, where the 'Keris' is an important spiritual and religious activity.

The 'Keris' genealogy explores the origin of the concept religiosity. According to Pusponegoro (2008) traditional society initially emphasized on the new symbolic aspects of religious magic and then processed it into an object that fulfills social functions and tectomics (functional) as a tool to adapt or incorporate its environment in order to maintain its survival. This has been described at the beginning of the roots of the emergence of a 'Keris' which is thought to have an influence from Dongson culture. 'Keris' is a manifestation of the religious concept as a vehicle / spirit boat to go to nirvana. In developments with the inclusion of Buddhist Buddhism, the position of the 'Keris' as part of its owner and to become a means of approaching supernatural substances. Along with the journey of the entry of Islam, 'Keris' is the stylization / writing of Allah. Whereas the people who embrace Christianity / Christian 'Keris' are the stylization of the symbol of the cross. This reality shows the flexibility of the 'Keris' as a cultural object, the flexible creativity of initiative can follow developments, changes, and placements in the context of trust.

This reality has become important to be reconstructed in the contemporary era, given that in the community's point of view a negative projective growth has begun which marginalizes the 'Keris' as a cultural object. This marginalization is caused by the strong point of view that the 'Keris' is part of heresy and needs to be shari'ah. Things that then require wisdom in a way of looking. Kris as a cultural object is a treasure of the archipelago's wealth. Apart from mystical values, religious 'Keris' is an aesthetic object. While understanding the context of belief at that time will be different from the current context, placing the 'Keris' not only as a magical object can be a means of preservation.

Moreover, in the present context, the 'Keris' has been confronted with an alternative culture (mass culture) which increasingly shows the 'Keris' as a 
relic with high aesthetic value. This shift has shown that the mindset of the lay group (the general public), the special group (intellect) and the new group (which considers the 'Keris' as an art object) brings and delivers the 'Keris' as a commodity, no longer a sacred matter but has become profane. The dynamics of the development of 'Keris' in the contemporary era are progressively functionalistic supporting the market, namely as goods with high exchange rates.

\section{CONCLUSION}

The world of 'Keris' with all its aspects shows in genealogy starting with the concept religiosity. 'Keris' is a vehicle manifestation / spirit prahu to go to nirvana. In developments with the inclusion of Buddhist Buddhism, the position of the 'Keris' as part of its owner and to become a means of approaching supernatural substances. Along with the journey of the entry of Islam, 'Keris' is the stylization / writing of Allah. Whereas the people who embrace Christianity / Christian 'Keris' are the stylization of the symbol of the cross. This reality shows the flexibility of the 'Keris' as a cultural object, the flexible creativity of initiative can follow developments, changes, and placements in the context of trust. The symbolization of the 'Keris' in the lay group (the general public) is more of a nature vertical-transdental. Whereas in the special group (intellect) the symbol of the Javanese kris has a double dimension, that is vertical-transdental, all at once horizontal-immanent. Whereas in the new group (which considers the 'Keris' as an art object) the symbol of the Javanese 'Keris' is more dimensional horizontal-immanent.

Further studies related to the relation of the 'Keris' and the beginning of the influence of the belief of Shiva are an interesting part of seeing how the transformation of the 'Keris' as a sacred object in Javanese society. This research is important given that global extremism forms ideal standards that lead to global cultural uniformity, which is not impossible to be destructive of the philosophical values of an ethnic entity. Viewing the 'Keris' is not merely a syncretic magical item and needs to be endorsed, because in its symbolic meaning the 'Keris' has religious philosophical values that apply universally. 'Keris' archeology is able to encourage the realization of cultural identity that strengthens nationalism in diversity rather than uniformity, creating awareness of the preservation of religious archeology as a form of religious cultural copyright. And it still exists now.

\section{REFERENCES}

Arifin, M.T. (2006). 'Keris' Jawa, Bilah Latar Sejarah hingga Pasar. Jakarta: Hajied Pustaka.

Budisutrisna. (2009). "Gambaran Manusia dalam 'Keris", Naskah Kearifan Nusantara. Yogyakarta: Kepel Press.

Cassirer. (1994). Manusia dan Kebudayaan: Sebuah Esai Tentang Manusia. Jakarta: Gramedia.

Darmojo, K.W.. (2016). Tinjauan Semiotika Terhadap Eksistensi 'Keris' dalam Budaya Jawa”. Brikolase Journal Vol. 8, No. 2 Desember hal. 67. 
Aji, Suryani, Masadad, EduLite: Journal of English Education, Literature, and Culture Vol.4, No.2, August 2019, 247-260 DOI: http://dx.doi.org/10.30659/e.4.2.247-260

Endraswara, S. (2013). Memayu Hayuning Bawana: Laku Menuju Keselamatan Hidup dan Kebahagiaan Hidup Orang Jawa. Yogyakarta: Naraso.

Endrawati, E. (2015). "Posisi 'Keris' pada Masyarakat Jogja Modern”, Journal Komunikasi Vol. 7. No. 2, Desember 2015. Hal. 137.

Geertz, C. (1992). Kebudayaan dan Agama. Yogyakarta: Kanisius.

Harsinuksmo, B. (2004). Ensiklopedi 'Keris'. Jakarta: Gramedia.

Herusatoto, B. (2008). Simbolisme dalam Budaya jawa, (Yogyakarta: Hanindita Graha Widia.

Koentjaraningrat. (1987). Penghantara Antropologi I. Jakarta: Puslit Arkesnas

Marwati djoenoed Pusponegoro dan Nugroho Notosusanto. (2008). Sejarah Nasional Indonesia i: zaman Prasejarah di Indonesia. Jakarta: Balaipustaka.

Munandar, A.A. (2010). "Kawasan Asia Tenggara dalam Dinamika Sejarah Kebudayaan", Majalah Arkeologi Indonesia, 4 Juli

Munro, T. (2007). Oriental Aesthetic, Terj. Heribertus B sutopo, Estetika Timur. Surakarta: Alumni Seni Rupa UNS.

Nurhadai. (1987). “Arkeologi: Enklaren dan Verstehen”, Journal Amerta, No. 10 hal. 15

Philipus, T, Wilhelmus, J. (1994). Agama-agama Kerabat dalam Semesta. Flores: Nusa Indah.

Prasena, R. (2009). Kekuatan Simbolik 'Keris'. Malang: Paguyuban Pecinta dan Pelestari Tosan Aji Nusantara.

Siswanto, N. (2012). "Metafisika Simbol 'Keris' Jawa”, Jurnal Filsafati, Vol. 22, No. 1 April, hal. 70.

Sumarjo, Y. (2002). Arkeologi Budaya Indonesia. Yogyakarta: Cv Qalom.

Susetya, W. (2007). Kontroversi Ajaran Kebatinan. Jakarta: Narasi.

Wach, J. (1984). Ilmu Perbandingan Agama. Jakarta: Rajawali.

Warto. (2015). "Makna Desain 'Keris' dalam Budaya Jawa”, Komunika, Vol. 2, No, 1 Desember, hal. 114.

Wijayanto, W., Sudrajat, U. (2011). 'Keris' dalam Perspektif Keilmuwan. Jakarta: Direktorat Jendral Kebudayaan.

Wisnu, Rangkai. (2012). Sangkan Paraning Dumadi. Jogjakarta: Diva Press.

Zoetmulder, P.J. (1965). The Significance of The Study of Culture on Religion for Indonesia Historiography dalam Soedjatmoko, dkk. An Introduction of Indonesia Historiography, (New York: Cornell University Press. 